\title{
Regio- and Stereoselective Synthesis of 2,3,5-Trienoates by Palladium-Catalyzed Alkoxycarbonylation of Conjugated Enyne Carbonates
}

\author{
Ezgi Şule Karagöz, Melih Kuş, Gürkan Eray Akpınar, and Levent Artok* \\ Department of Chemistry, Faculty of Science, Izmir Institute of Technology, Urla 35430, Izmir Turkey
}

Supporting Information

ABSTRACT: Palladium-catalyzed carbonylation of 2,4-enyne carbonates in an alcohol and under balloon pressure of $\mathrm{CO}$ proceeds through 1,5-substitution to yield (E)-2,3,5-trienoates. The olefin geometry of the substrate is important to control the overall stereochemistry of this alkoxycarbonylation method. The reaction proceeds through successive formation of $\pi$-allylpalladium with an $\mathrm{R}^{3}$ group oriented syn and $\sigma$-allenyl palladium complexes.

\section{INTRODUCTION}

The development of synthetic methods for the construction of allenes with diverse arrangements of functional groups, ${ }^{1}$ particularly in an enantioselective manner, ${ }^{2}$ has been of longstanding interest because allenes are widely utilized as building blocks, ${ }^{3}$ for translating axial chirality to central chirality, and as a considerable number of naturally occurring and biopotent compounds contain allene units. ${ }^{1,4}$

$\operatorname{Pd}(0)$-catalyzed reactions of propargylic reagents usually afford $\sigma$-allenyl palladium species, ${ }^{5}$ and the formation of this intermediate has been a strategy widely applied for the synthesis of functionalized allenyl structures. ${ }^{2 a, b, 4 a, 6}$ Moreover, enantiomerically enriched propargyl reagents with relatively good leaving groups such as cyclic carbonate, ${ }^{7}$ mesylate, ${ }^{4 a, 8}$ phosphate, $^{9}$ and oxirane ${ }^{10}$ have been found to translate the chirality center to the three carbon axis of the allenyl products with good enantiomeric excesses (ee). In addition, only recently have successful examples of asymmetric carbonylation of racemic propargylic carbonates that led to access optically active 2,3-allenoates with fairly high ee been demonstrated. ${ }^{2 b}$

We have reported in our preliminary communication that the $\operatorname{Pd}(0)$-catalyzed carbonylation of carbonates of secondary $(Z)$ 2-en-4-yne alcohols also proceeds through the involvement of an $\pi$-allenylpalladium intermediate, furnishing 2,3,5-trienoates in high yields (Scheme 1). ${ }^{11}$ The method is completely diastereoselective, with donated vinylallene products with a

Scheme 1. Alkoxycarbonylation of (Z)-Enyne Carbonates ${ }^{11}$<smiles>[R]/C(C#[R]OC)=C/C([R])OC(C)=O</smiles>

$(Z)-1$

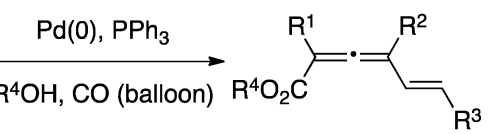

2

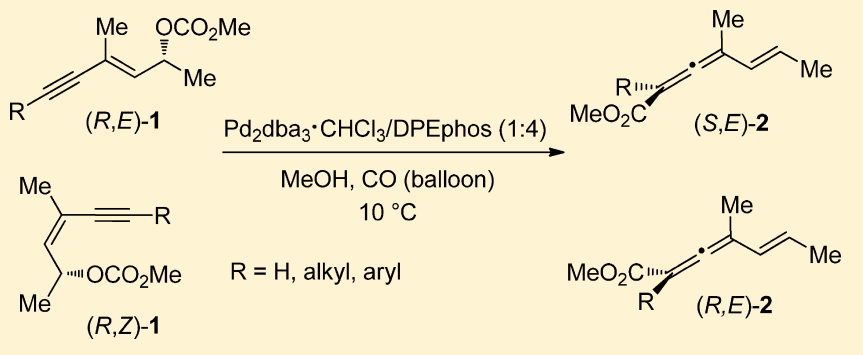

vinylic group exclusively in the $(E)$ configuration. However, no indication of chirality transfer from center-to-axial could be demonstrated for these reactions since the palladium-catalyzed reactions of enantiopure enyne carbonate substrates under the established conditions all led to racemic vinylallene products. $^{11,12}$

In that report, we have concluded that only (Z)-isomers of the enyne carbonate substrates were capable of taking part in this carbonylation reaction because the methoxycarbonylation of the substrate $(E)$-1a under the conditions established therein led to a complex mixture and consequently gave a low yield of the expected product 2aa (Scheme 2). ${ }^{11}$ Repetitive trials by different hands has also resulted in similar failures.

We have realized later that the incompatibility of the established methodology is specifically peculiar to $(E)-1$ a. We have found upon further study that, as reported herein, $(E)$ enyne carbonates are also applicable substrates. ${ }^{11}$ Moreover, a good to excellent level of center-to-axial chirality transfer would be possible upon modification of the reaction conditions. In addition, observed stereoselectivity of the process, as well as structural features of various byproducts identified during several reactions, provided more information for the mechanism underlying the method.

It should also be noted that the results obtained here override our previously proposed notion that the reaction is promoted via the cooperative coordination of palladium with both alkynyl and carbonate moieties ${ }^{11}$ because (E)-enyne carbonates, which proved high activity toward palladium catalysis as a means to synthesize vinylallenes as presented here and elsewhere, ${ }^{12}$ are not capable of taking part in such a dual interaction due to geometrical constraints.

Received: July 21, 2014

Published: September 4, 2014 
Scheme 2. Methoxycarbonylation of (E)-1a

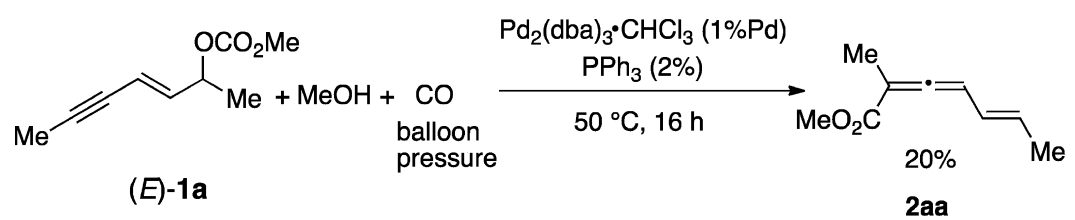

\section{RESULTS AND DISCUSSION}

At the outset of this study, the applicability of (E)-enyne carbonates toward alkoxycarbonylation reactions were evaluated using the conditions previously employed for $(Z)$ configured enyne carbonates, that is, $\mathrm{Pd}_{2} \mathrm{dba}_{3} \cdot \mathrm{CHCl}_{3}(1 \% \mathrm{Pd})$, $2 \% \mathrm{PPh}_{3}, 5 \mathrm{~mL}$ of alcohol, at $50{ }^{\circ} \mathrm{C}$ and under a CO-filled balloon. First, (E)-1b was subjected to alkoxycarbonylation reactions with several alcohols under these conditions. The results obtained from the alkoxycarbonylation reactions of $(E)$ $\mathbf{1 b}$ with $\mathrm{MeOH}$ and primary $\mathrm{C}_{2}-\mathrm{C}_{4}$ alcohols all proved to be comparable to those obtained with $(Z)-\mathbf{1} \mathbf{b}$; the high yield of the desired vinylallene ester products (2ba-bd, 80-91\%) were obtained in each case (Table 1 , entries 1-4). However, a moderate yield (67\%) of $\mathbf{2 b e}$ was recovered from the reaction of $(E)-\mathbf{1 b}$ and isopropyl alcohol (entry 5).

Table 1. Alkoxycarbonylation of (E)-Enyne Carbonate $2 b^{a}$

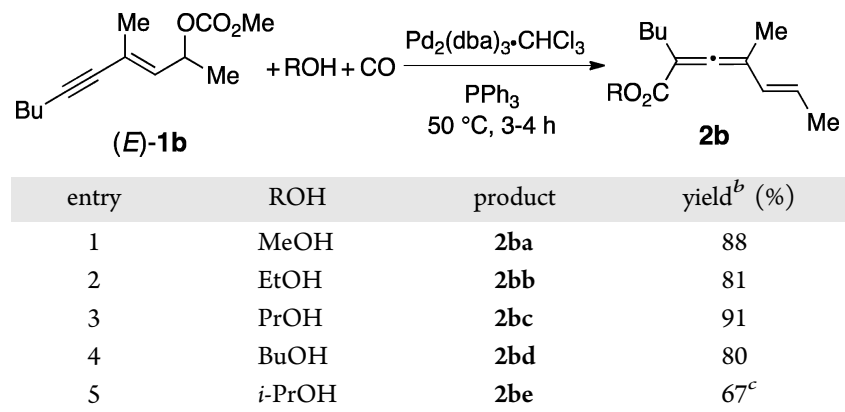

${ }^{a}$ Substrate $\mathbf{1 b}(0.3 \mathrm{mmol}), \mathrm{ROH}(5 \mathrm{~mL})$, CO (balloon pressure), 1 $\mathrm{mol} \%$ of $\mathrm{Pd}, 2 \mathrm{~mol} \%$ of $\mathrm{PPh}_{3}$. ${ }^{b}$ Isolated yield. ${ }^{c} 6 \mathrm{~h}$.

The carbonylation reactions were also performed with an array of $(E)$-enyne carbonates in methanol (Table 2). The conversions of enyne carbonate substrates, with 2,3,5-trienoates identified as the sole products, were generally complete within 4-6 $\mathrm{h}$ regardless of the size and electronic nature of the substituents. The method is perfectly suitable for enynes bearing a methyl (1c), phenyl (1d), cyclohexyl (1e), or highly cumbersome tert-butyl (1f) groups on the alkynyl moiety $\left(\mathrm{R}^{1}\right)$, providing the desired products in moderate to high yields (entries 1-4). The methodology can also tolerate without problem the enyne carbonate with disubstituted alkenyl moiety $\left(\mathrm{R}^{2}=\mathrm{H}\right)$ or those bearing butyl or phenyl groups on the alkenyl carbon $\left(\mathrm{R}^{2}\right)$ that is proximal to the alkynyl moiety, affording the desired products $2 \mathrm{ga}-\mathrm{ia}$ within the range of $77-$ $90 \%$ yields (entries $5-7$ ). In contrast, however, an $(E)$ and $(Z)$ isomeric mixture of the substrate $\mathbf{1} \mathbf{j}$, where the $R^{2}$ position is occupied by a bulky tert-butyl group which favored the formation of an allylic carbonylation (3ja) and methoxylation $(4 \mathrm{ja})^{13}$ products, afforded, therefore, the expected trienoate product $(2 \mathbf{j a})$ in a negligible amount (entry 8$)$.

The effect of variation of allylic substitution $\left(\mathrm{R}^{3}\right)$ on the activity of the enyne carbonate was also assessed. The method was rather successful also for the enyne substrates in which $R^{3}$ was butyl $((E)-1 \mathbf{k}, 76 \%)$ or isopropyl $((E)-11,92 \%)$ groups (entries 9 and 10).

It is worthy of note that in contrast to the activity of $(Z)$ configured enyne carbonates the $(E)$-enyne carbonates showed much less reactivity dependence on the size of substituents; a longer reaction time or a higher reaction temperature was required for complete conversion of the $(Z)$-isomer as it is endowed with bulkier groups. ${ }^{11}$ This lower tolerance of the method on larger substituents on $(Z)$-isomers may be related to their overall more sterically congested structure as compared to their $(E)$-configured counterparts.

The methoxycarbonylation of an enyne carbonate of a primary alcohol $\left(\mathrm{R}^{3}=\mathrm{H}\right)$ led to a mixture of vinylallene product $2 \mathrm{ma}$ and ester functionalized 2-en-4-yne (3ma') byproduct (entry 11).

The method is also not suitable for an enyne carbonate substrate that bears a phenyl group on the allylic position, which resulted in a pair of allylic ethers and no traces of any carbonylative product was observed to form (entry 12).

Another substrate that failed to yield the desired vinylallene product carried a methyl group on the alkenyl carbon that is distal to the alkynyl moiety $((E)-10)$, which led to intricate mixture during the methoxycarbonylation reaction (Scheme 3).

Having revealed the scope and limitation of the method, next we attempted to explore its stereoselectivity using the carbonates of enantiopure secondary enynols which were prepared from corresponding racemic enynols by employing Sharpless's kinetic resolution method (Scheme 4). ${ }^{14}$

The outcome of a methoxycarbonylation reaction of an enantioenriched enyne carbonate $(R, E)-\mathbf{1 b}$ under the aforementioned optimal conditions was rather frustrating; the vinylallene product $(S)$-2ba was obtained with fairly low ee (Table 3, entry $1, \sim 17 \%$ ee). ${ }^{15}$ Application of the reaction at 26 ${ }^{\circ} \mathrm{C}$ and at a higher catalyst loading level $(2 \mathrm{~mol} \% \mathrm{Pd}$ and $4 \mathrm{~mol}$ $\% \mathrm{PPh}_{3}$ ) offered only a slight improvement for the ee (entry 2 ). Nevertheless, it was encouraging to observe that doubling the ligand-to-palladium ratio to $4: 1$ improved the ee up to $54 \%$, although it required a longer reaction period for the complete conversion of $(S)$-2ba when the reaction was performed at 26 ${ }^{\circ} \mathrm{C}$ (entry 3). The coordinative saturation of palladium with the phosphine ligand probably brought about a decrease in the reactivity of the metal center toward the oxidative addition step, leading to a $\pi$-allylpalladium complex ${ }^{16}$ that led to a decrease in the reaction rate yet proved useful in regard to the enantiomeric grade of the product. ${ }^{17}$

Replacement of the in situ formed a palladium-phosphine catalyst system with a preprepared catalyst $\mathrm{Pd}\left(\mathrm{PPh}_{3}\right)_{4}$ showed no beneficial effect on either the reactivity or enantiocontrol ability of the method (entry 4).

Keeping the $\mathrm{P} / \mathrm{Pd}$ ratio at $4: 1$, several mono- and bidentate ligands were also surveyed in an attempt to improve the stereoselectivity of this alkoxycarbonylation method. The conversion of $(R, E)-\mathbf{1 b}$ at $26{ }^{\circ} \mathrm{C}$ was incomplete when an electron-poor ligand was used, thus giving rise to a low yield of 2ba (entry 5). Electron-rich bidentate phosphine ligands 
Table 2. Pd(0)-Catalyzed Methoxycarbonylation of (E)-Enyne Carbonates ${ }^{a}$

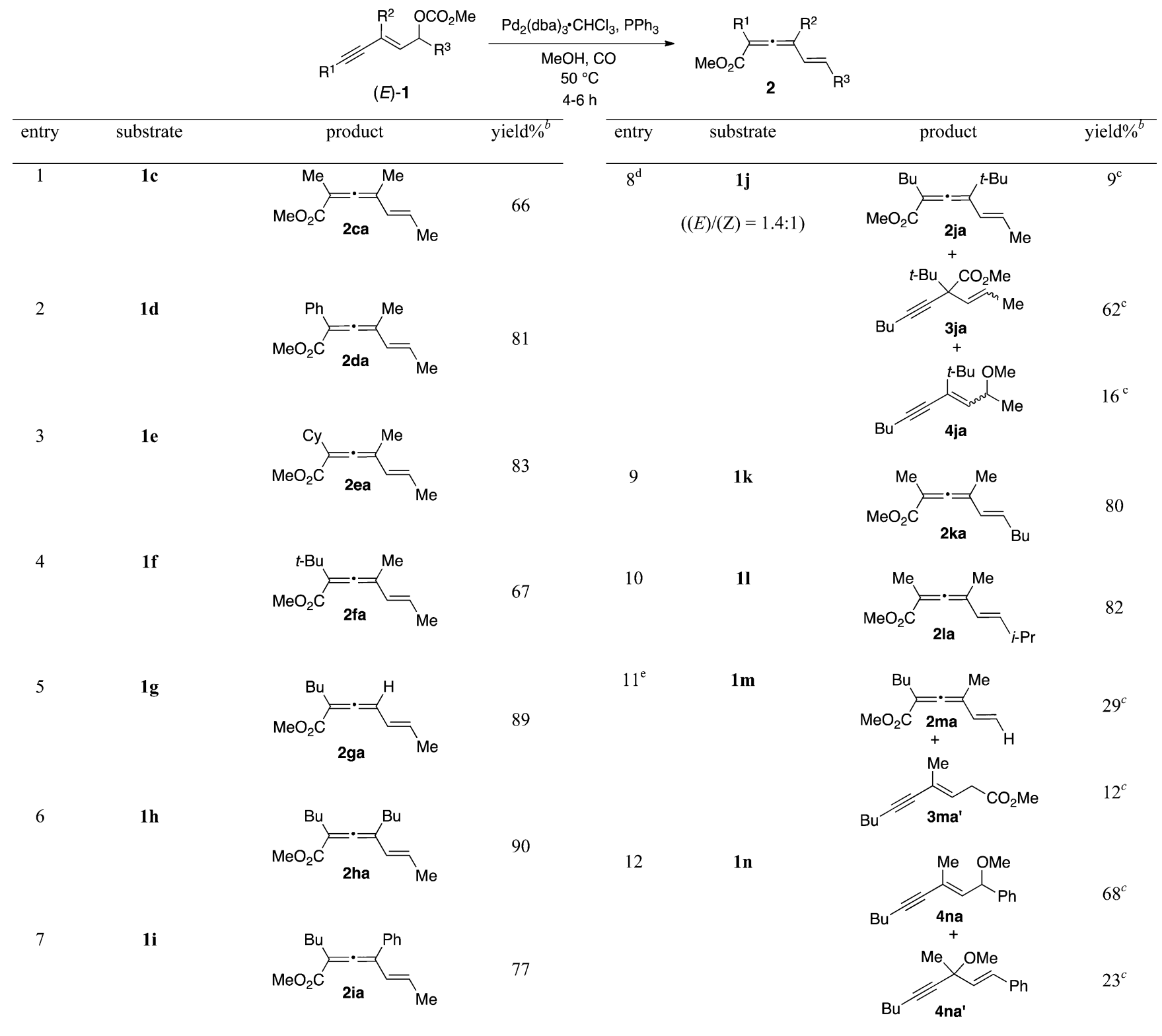

${ }^{a}$ Substrate 1 ( $\left.0.3 \mathrm{mmol}\right), \mathrm{MeOH}(5 \mathrm{~mL}), \mathrm{CO}$ (balloon pressure), $1 \mathrm{~mol} \%$ of $\mathrm{Pd}, 2 \mathrm{~mol} \%$ of $\mathrm{PPh}_{3} \cdot{ }^{b}$ Isolated yield. ${ }^{c}$ Isomeric ratio was determined by ${ }^{1} \mathrm{H}$ NMR. ${ }^{d} 2 \mathrm{~mol} \%$ of Pd, $4 \mathrm{~mol} \%$ of $\mathrm{PPh}_{3}, 22 \mathrm{~h} .13 \%$ of $1 \mathrm{j}$ was recovered with an $E / Z$ ratio of 1:2. ${ }^{e}$ The conversion was incomplete after $24 \mathrm{~h}$.

Scheme 3. Pd(0)-Catalyzed Methoxycarbonylation of $(E)-10$<smiles>CC#C/C=C(\C)C(C)OCC(=O)OCCOC</smiles>

$(E)-10$

Scheme 4. Synthesis of Enantiopure 2,4-Enynols by the Sharpless Method

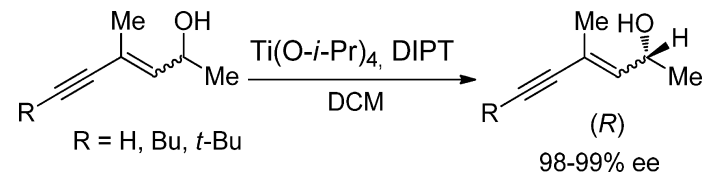

resulted in a better performance; the use of Xanthphos enabled the formation of $(S)-2$ ba with $62 \%$ ee and $93 \%$ yield (entry 6).
Nevertheless, the most dramatic impact on both the reactivity and the stereoselectivity of the method was observed by the use of DPEphos ligand; the reaction rate was significantly accelerated in the presence of this ligand in the reaction medium, which allowed the formation of (S)-2ba with $90 \%$ yield and $72 \%$ ee after $4 \mathrm{~h}$ of reaction at $26{ }^{\circ} \mathrm{C}$ (entry 7 ). Elevation of the reaction temperature was detrimental for the selectivity of the method (entry 8). However, further improvement was still possible $\left(82 \%\right.$ ee, $[\alpha]^{22}{ }_{\mathrm{D}}=+14.7(c=$ $\left.0.68, \mathrm{CH}_{2} \mathrm{Cl}_{2}\right)$ ) by performing the reaction at $10{ }^{\circ} \mathrm{C}$ (entry 9 ), but no benefit was gained from further lowering the reaction temperature to $0{ }^{\circ} \mathrm{C}$ (entries 10 and 11).

Molander et al. reported that vinylallenes are relatively reactive components toward enantiomerization under palladium-mediated conditions. ${ }^{9 \mathrm{~b}}$ To test such a possibility, the enantioenriched vinylallene compound $(S)$-2ba ( $82 \%$ ee) was subjected to a methoxycarbonylation process at both 26 and 10 
Table 3. Palladium-Catalyzed Methoxycarbonylation of $(R, E)-1 b^{a}$

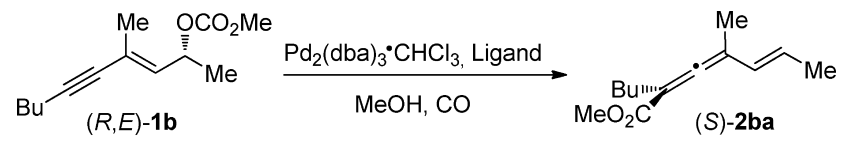

$98 \%$ ee

\begin{tabular}{|c|c|c|c|c|c|c|}
\hline entry & $\begin{array}{c}\mathrm{Pd} \\
(\%)\end{array}$ & ligand (\%) & $\begin{array}{c}\mathrm{T} \\
\left({ }^{\circ} \mathrm{C}\right)\end{array}$ & $\begin{array}{c}\text { time } \\
(\mathrm{h})\end{array}$ & $\begin{array}{l}\text { ee } \\
(\%)\end{array}$ & $\begin{array}{c}\text { yield }^{b} \\
(\%)\end{array}$ \\
\hline 1 & 1 & $\mathrm{PPh}_{3}(2)$ & 50 & 4 & 17 & 90 \\
\hline 2 & 2 & $\mathrm{PPh}_{3}$ (4) & 26 & 9 & 21 & 91 \\
\hline 3 & 2 & $\mathrm{PPh}_{3}(8)$ & 26 & 20 & 54 & 90 \\
\hline 4 & 2 & $\mathrm{Pd}\left(\mathrm{PPh}_{3}\right)_{4}$ & 26 & 40 & 50 & 91 \\
\hline 5 & 2 & $\mathrm{P}\left(4-\mathrm{CF}_{3} \mathrm{C}_{6} \mathrm{H}_{4}\right)_{3}(8)$ & 26 & 25 & 58 & $56^{c}$ \\
\hline 6 & 2 & Xantphos (4) & 26 & 27 & 62 & 93 \\
\hline 7 & 2 & DPEphos (4) & 26 & 4 & 72 & 90 \\
\hline 8 & 1 & DPEphos (2) & 50 & 3 & 64 & 91 \\
\hline $9^{d, e}$ & 2 & DPEphos (4) & 10 & 13 & 82 & 93 \\
\hline $10^{d}$ & 2 & DPEphos (4) & 0 & 45 & 77 & 84 \\
\hline $11^{d}$ & 5 & DPEphos (10) & 0 & 21 & 70 & 93 \\
\hline
\end{tabular}

${ }^{a}$ Substrate $(R, E)-\mathbf{2 b}(0.1 \mathrm{mmol}), \mathrm{MeOH}(1.7 \mathrm{~mL}), \mathrm{CO}$ (balloon pressure), Xanthphos (4,5-bis(diphenylphosphino)-9,9-dimethylxanthene), DPEphos (bis-[2-(diphenylphosphino)phenyl] ether). ${ }^{b}$ Isolated yield. ${ }^{c}$ The reactant was recovered by $31 \% .{ }^{d}(R, E)-1 \mathbf{b}(0.3$ $\mathrm{mmol}), \mathrm{MeOH}(5 \mathrm{~mL}) .{ }^{e}$ For the product of this reaction, $[\alpha]_{\mathrm{D}}^{22}=$ $+14.7\left(c=0.68, \mathrm{CH}_{2} \mathrm{Cl}_{2}\right)$.

${ }^{\circ} \mathrm{C}$ using a Pd/DPEphos combination under the conditions given for entry 9. Indeed, the substrate $(S)$-2ba underwent partial racemization to give product of $58 \%$ ee after $8 \mathrm{~h}$ of treatment at $26{ }^{\circ} \mathrm{C}$, whereas no marked variation in enantiopurity of $(S)$-2 ba could be determined after $24 \mathrm{~h}$ of treatment at $10{ }^{\circ} \mathrm{C}$, indicating that at the lower reaction temperature employed any loss of stereoselectivity during the transformation of $\mathbf{1}$ to $\mathbf{2}$ chiefly takes place in the course of the reaction cycle, not due to the Pd-promoted enantiomerization of the product vinylallene.

The chirality transfer test was also attempted for $(R, Z)-\mathbf{1 b}$ substrate; the reaction with $(R, Z)-\mathbf{1 b}$ proceeded more sluggishly, and the reaction period was lengthened to $48 \mathrm{~h}$ for complete conversion, yielding the vinylallene product in opposite configuration $((R)-\mathbf{2 b a}, 79 \%$ ee) as compared to that obtained from the substrate $(R, E)-1 \mathbf{b}$ (Scheme 5, eq 1). These results suggest that the stereoselectivity depends on the olefin geometry of enyne carbonate.

It was intriguing to verify that there appears to be a direct relation between the enantiocontrol ability of the method and the size of the group on the alkynyl terminus (Scheme 5). ${ }^{18}$ Whereas methoxycarbonylation of an enantioenriched enyne carbonate $(R, E)$-1p with a terminal alkynyl group proceeded with partial racemization ( $44 \%$ ee, $90 \%$ yield) (eq 2), an excellent level of chirality transfer could be attained during the reaction of the enyne carbonate $(R, E)$-1f carrying a tert-butyl group on the alkynyl terminus, which delivered $(S)$-2fa with $89 \%$ yield and $96 \%$ ee, albeit with longer reaction time and higher Pd loading to complete the reaction (eq 3). To our knowledge, this catalytic reaction has been the first example of Pd-catalyzed coupling reaction proceeding with an efficient remote stereocontrol for conjugated enyne structures with a leaving group on the allylic carbon. ${ }^{19}$

In regard to the reaction mechanism, the catalytic cycle should begin with oxidative addition of $(R, E)-\mathbf{1}$ and $(R, Z)-\mathbf{1}$ to $\operatorname{Pd}(0)$ in order to afford $\pi$-allylpalladium complexes 5 and $\mathbf{6}$, respectively, by displacement of the leaving group with inversion (Scheme 6). ${ }^{16,21}$ The $\mathrm{R}^{3}$ group on both complexes is oriented syn with respect to the middle allylic $\mathrm{C}-\mathrm{H}$ in order to furnish vinylallene products ultimately in the $(E)$ configuration. However, while $\mathrm{R}^{2}$ is inherently anti oriented on the initially formed intermediate 5 , it is syn in the case of 6 . Furthermore, the $\pi$-allylpalladium complexes 5 and 6 may be

Scheme 5. Methoxycarbonylation of Enantiopure Enyne Carbonates ${ }^{20}$
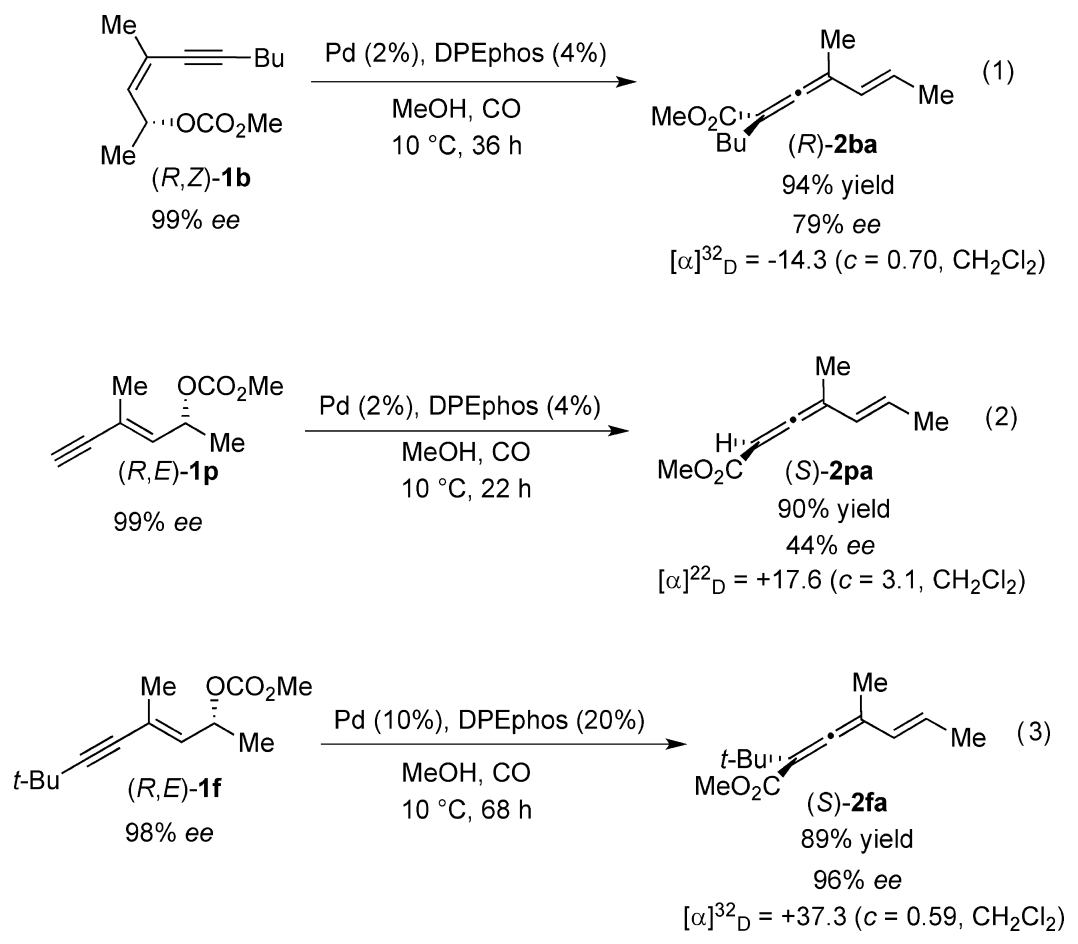
Scheme 6. Mechanism of Alkoxycarbonylation of 2-En-4-yne Carbonates
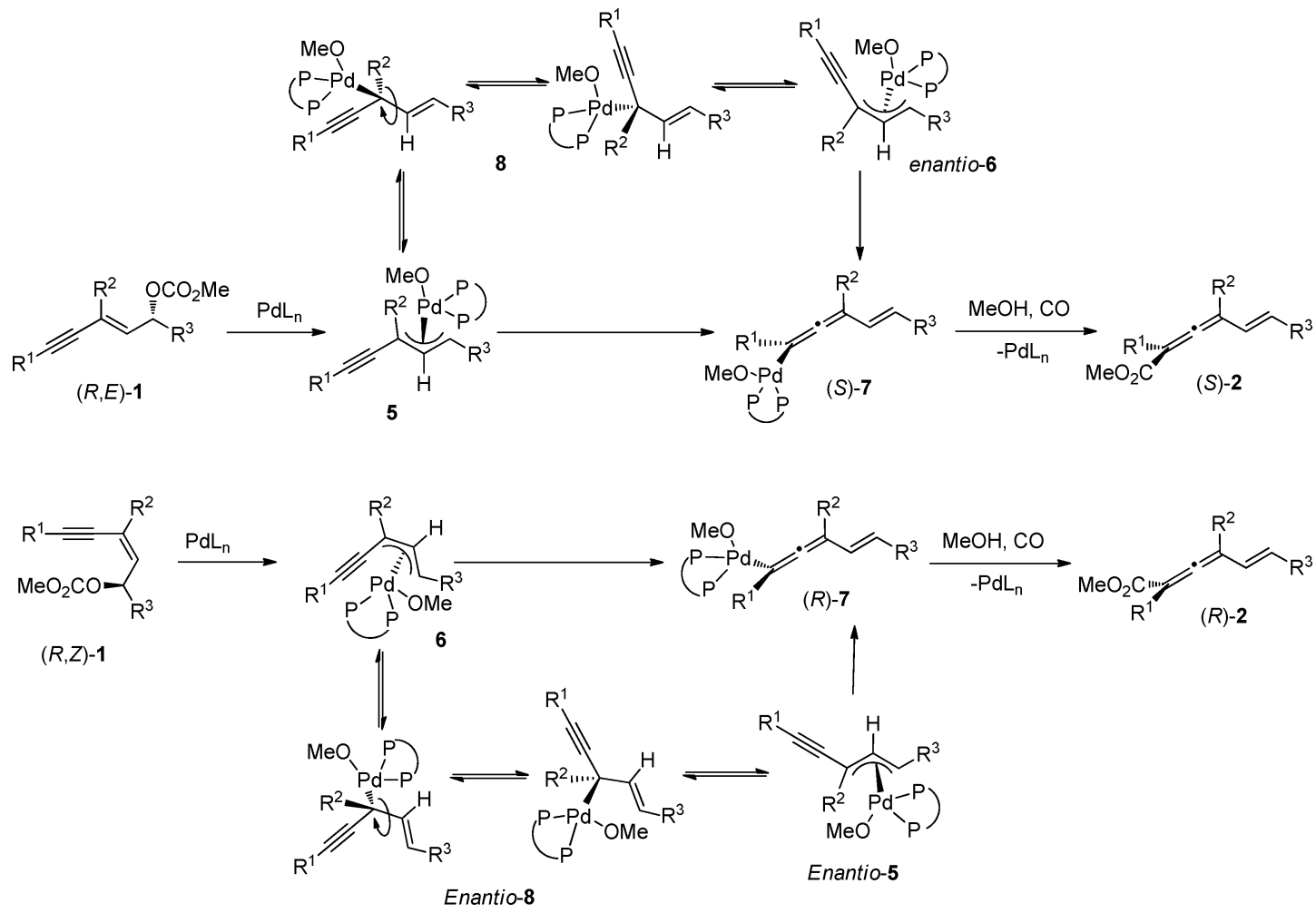

Scheme 7. Formation of Byproducts from the Methoxycarbonylation Reactions of $1 \mathrm{j}, \mathrm{m}, \mathbf{n}$

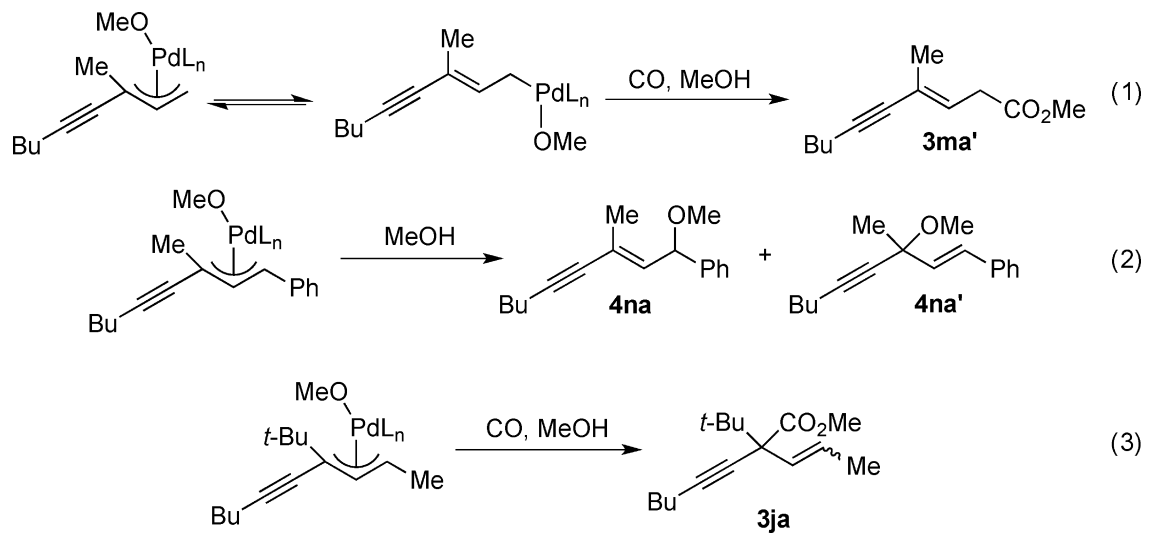

converted crosswise into the enantiomers of each other, enantio- 6 and enantio-5, respectively, via the well-known the $\pi-\sigma-\pi$ interconversion. $^{22}$

Subsequently, all these intermediates may undergo a palladium shift to the distal alkynyl carbon mainly by retention of the configuration with accompanying isomerization of $\pi$ electrons to afford $\sigma$-allenyl palladium complexes $(S)-7$ and $(R)-7$. While both 5 and enantio- 6 are able to lead to $(S)-7$, (R)-7 could be derived from both 6 and enantio-5. The favored position of $\mathrm{R}^{2}$ and alkynyl groups (syn or anti) on $\pi$ allylpalladium intermediate, which will involve in the next step of the mechanism, would probably be determined by the thermodynamic stability of the allylic ligand. ${ }^{16 a, b, 21}$ Finally, the $(S)-7$ and $(R)-7$ undergo sequential CO insertion followed by reductive elimination to furnish vinylallene products $(S)-2$ and (R)-2, respectively.

The formation of allylic substituted byproducts from the corresponding reactions of $\mathbf{1 j}, \mathbf{1} \mathbf{m}$, and $\mathbf{1 n}$ (see Table 2, entries
8,11 , and 12) are well in line with the proposed mechanism; the conversion of these substrates to nonallenic products also should involve $\pi$-allylpalladium intermediates. The formation of a relatively stable primary $\sigma$-allylpalladium intermediate should be responsible for the formation of the enyne ester byproduct 3ma' (Scheme 7, eq 1 ). The relatively higher electrophilic nature and greater stability of $\pi$-allyl intermediate where the allylic system is conjugated to the phenyl substituent in comparison to its alkyl-substituted analogues unfavors the palladium shift to generate $\sigma$-allenylpalladium complex but rather undergoes methanol attack to give 4na and 4na' (eq 2). ${ }^{23}$

The substrate $\mathbf{1 j}$ contains a bulky tert-butyl group on the alkenyl group that hinders the migration of the $\pi$-allyl coordinated palladium to the alkynyl side, hence partly undergoing allylic methoxycarbonylation (eq 3). 


\section{CONCLUSION}

In this report, a scope of alkoxycarbonylation reactions of carbonates of (E)-2-en-4-yne alcohols leading to 2,3,5trienoates with an exclusively $(E)$-configuration is presented. It has been found on the basis of the reactions, which were performed over enantiopure reagents, that the geometry of the alkenyl moiety $((E)$ or $(Z))$ controls the stereoselectivity of the process. It was also observed that the extent to which center-toaxis chirality transfer occurs is remarkably dependent on the size of the substituent on the alkynyl terminus. On the basis of the stereochemical outcome of the process, as well as structural features of byproducts identified, we have envisaged that the reactions should involve successive formations of $\pi$-allylpalladium with an $\mathrm{R}^{3}$ group located syn with respect to the middle allylic $\mathrm{C}-\mathrm{H}$ and $\sigma$-allenylpalladium complexes for generating the $(E)-2,3,5$-trienoates.

\section{EXPERIMENTAL SECTION}

General Methods. Tetrahydrofuran (THF) and dichloromethane (DCM) solvents were all purified by a solvent purification system. $\mathrm{Et}_{2} \mathrm{O}$ was distilled from benzophenone ketyl under argon prior to use. Methanol and ethanol were dried over $\mathrm{Mg}$ turnings in the presence of iodine and stored on 3A molecular sieves under Ar. Drying of 1propanol and 2-propanol were performed first by stirring over anhydrous $\mathrm{CaO}$ and then refluxing over $\mathrm{Mg}$ turnings in the presence of iodine. 1-Butanol was dried first by stirring over anhydrous $\mathrm{MgSO}_{4}$ and followed by refluxing over $\mathrm{Mg}$ turnings in the presence of iodine. The $\mathrm{Pd}_{2}(\mathrm{dba})_{3}-\mathrm{CHCl}_{3}$ complex was synthesized in the laboratory. ${ }^{24}$

All of the synthesized reactants and carbonylation products were isolated by column chromatography using a hexane-ethyl acetate eluent and analyzed by GC-MS, NMR, and FTIR techniques. NMR $(400 \mathrm{MHz})$ spectra were recorded in $\mathrm{CDCl}_{3}$ or $\mathrm{C}_{6} \mathrm{D}_{6}$. Infrared spectra were obtained by the ATR method with neat samples. High-resolution mass spectral analyses of new compounds were performed using an EIhigh resolution double focusing magnetic sector (ionization mode: 70 $\mathrm{eV}$, emission current: $1 \mathrm{~mA}$, source temperature: $160{ }^{\circ} \mathrm{C}$, resolution: 10000 (10\% valley definition)), ESI-LTQ Orbitrap (source voltage: $+3.8 \mathrm{kV}$, capillary voltage: $41 \mathrm{~V}$, capillary temperature: $275^{\circ} \mathrm{C}$, tube lens voltage: $140 \mathrm{~V}$, system resolution: 60000 (10\% valley definition)), and ESI-Q-TOF (capillary voltage: $4.5 \mathrm{~V}$, fragmentor voltage: $175 \mathrm{~V}$, gas temperature $325^{\circ} \mathrm{C}$, resolution: $4 \mathrm{GHz}$ ) mass spectrometers.

Synthesis of Substrates $(E)-1 a-c, k-m, p$. The synthesis procedure and spectrometric data of the starting material compounds (E)-1a-c,k,l can be found elsewhere. ${ }^{11,12}$

The substrates $(E)-1 \mathrm{~m}(25 \%$ over six steps, $3.9 \mathrm{~g})$ and $(E)-1 \mathrm{p}(64 \%$ over three steps, $1.08 \mathrm{~g}$ ) were prepared following our previous report starting from (E)-3-methylpent-2-en-4-yn-1-ol reagent, ${ }^{12}$ which appeared as a colorless oil.

(E)-1m: ${ }^{1} \mathrm{H}$ NMR $\left(400 \mathrm{MHz}, \mathrm{CDCl}_{3}\right) \delta 5.83(\mathrm{t}, J=7.2 \mathrm{~Hz}, 1 \mathrm{H})$, $4.67(\mathrm{~d}, J=7.2 \mathrm{~Hz}, 2 \mathrm{H}), 3.77(\mathrm{~s}, 3 \mathrm{H}), 2.29(\mathrm{t}, J=6.8 \mathrm{~Hz}, 2 \mathrm{H}), 1.85(\mathrm{~s}$, $3 \mathrm{H}), 1.53$ (quint, $J=7.2 \mathrm{~Hz}, 2 \mathrm{H}), 1.41(\mathrm{sext}, J=7.2 \mathrm{~Hz}, 2 \mathrm{H}), 0.91(\mathrm{t}, J$ $=7.2 \mathrm{~Hz}, 3 \mathrm{H}) ;{ }^{13} \mathrm{C} \mathrm{NMR}\left(101 \mathrm{MHz}, \mathrm{CDCl}_{3}\right) \delta 155.8,127.9,124.9$, 90.1, 82.5, 64.1, 54.9, 30.9, 22.1, 19.1, 18.2, 13.7; FTIR $\left(\nu_{\max } / \mathrm{cm}^{-1}\right)$ 2958, 2933, 2873, 2219, 1748, 1442, 1378, 1329, 1254, 943, 791; MS (EI, $m / z) 210\left(2, \mathrm{M}^{+}\right), 168$ (16), $151(22), 135(30), 119$ (8), 109 (16), 105 (20), 95 (71), 92 (100), 91 (71), 81(30), 79 (53), 77 (42); HRMS (EI) calcd for $\mathrm{C}_{12} \mathrm{H}_{18} \mathrm{O}_{3} 210.1251$, found 210.1257 .

(E)-1p: ${ }^{1} \mathrm{H}$ NMR $\left(400 \mathrm{MHz}, \mathrm{C}_{6} \mathrm{D}_{6}\right) \delta 5.84(\mathrm{dq}, J=8.0,6.5 \mathrm{~Hz}$, $1 \mathrm{H}), 5.56(\mathrm{~d}, J=8.0 \mathrm{~Hz}, 1 \mathrm{H}), 3.34(\mathrm{~s}, 3 \mathrm{H}), 2.80(\mathrm{~s}, 1 \mathrm{H}), 1.58(\mathrm{~d}, J=$ $1.2 \mathrm{~Hz}, 3 \mathrm{H}), 1.26(\mathrm{~d}, J=6.4 \mathrm{~Hz}, 3 \mathrm{H}) ;{ }^{13} \mathrm{C}$ NMR $\left(100 \mathrm{MHz}, \mathrm{C}_{6} \mathrm{D}_{6}\right) \delta$ 155.6, 138.0, 120.4, 83.4, 81.4, 73.8, 54.1, 22.7, 20.2; FTIR $\left(\lambda_{\max }\right)$ $\left.\mathrm{cm}^{-1}\right)$ 2957, 2931, 2860, 2244, 146 1441, 1258, 1033, 944, 791, 762, 697; MS (EI, $m / z) 168\left(2, \mathrm{M}^{+}\right), 153(4), 109$ (100), 91 (77), 77 (44); HRMS (EI) calcd for $\mathrm{C}_{9} \mathrm{H}_{12} \mathrm{O}_{3}$ 168.0781, found 168.0780 .

Synthesis of Substrate (E)-1d. (E)-3-Methylpent-2-en-4-yn-1-ol (S1) was phenylated by the Sonogashira method: A mixture of phenyl iodide $(19 \mathrm{mmol}), \mathrm{PdCl}_{2}\left(\mathrm{PPh}_{3}\right)_{2}(105.3 \mathrm{mg}, 0.15 \mathrm{mmol})$, and $\mathrm{CuI}$
(16.5 mg, $0.085 \mathrm{mmol}$ ) was stirred in $70 \mathrm{~mL}$ of $\mathrm{Et}_{3} \mathrm{~N}$ for $3 \mathrm{~min}$ at 50 ${ }^{\circ} \mathrm{C}$ under $\mathrm{Ar}$, and then to this mixture was added $10 \mathrm{~mL}$ of $\mathrm{Et}_{3} \mathrm{~N}$ solution of $\mathrm{S1}(\sim 17 \mathrm{mmol})$. The mixture was again stirred at $50{ }^{\circ} \mathrm{C}$ for $3 \mathrm{~h}$. At the end of the reaction, water was added to the resulting mixture and then extracted with $\mathrm{Et}_{2} \mathrm{O}$. The combined organic layers were dried over $\mathrm{MgSO}_{4}$. The solvent was evaporated in vacuo, and the product (E)-3-methyl-5-phenylpent-2-en-4-yn-1-ol (S2d) was purified by column chromatography on silica gel (hexane/ethyl acetate, $2.5 \mathrm{~g}$, $85 \%)$. S2d was oxidized to the corresponding enyne aldehyde structure and then subjected to Grignard reaction with $\mathrm{MeMgBr}$ following the procedures as described previously ${ }^{12,13}$ to obtain $(E)-4$ methyl-6-phenylhex-3-en-5-yn-2-ol (S3d) compound (1.75 g, 65\%). Carbonate derivatization of S3d was performed via a prescribed method (0.88 g, 50\%). ${ }^{25}$ The spectrometric data of this starting material can be found elsewhere. ${ }^{12}$

Synthesis of Substrates $(E)-1 e, f, h-j$. Syntheses of these enyne substrates involve palladium-catalyzed conjugate addition of terminal alkynes to alkynyl esters through two established methods.

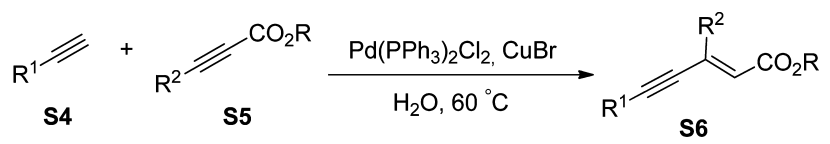

If $\mathrm{R}^{2}=\mathrm{Ph}, \mathrm{R}=\mathrm{Et}$; for others $\mathrm{R}=\mathrm{Me}$

Method A. A mixture of terminal alkyne (S4) $(50 \mathrm{mmol})$, alkynoic ester (S5) $(25 \mathrm{mmol}), \mathrm{CuBr}(225 \mathrm{mg}, 1.25 \mathrm{mmol})$, and $\mathrm{PdCl}_{2}\left(\mathrm{PPh}_{3}\right)_{2}$ $(465 \mathrm{mg}, 0.625 \mathrm{mmol})$ in $50 \mathrm{~mL}$ water was stirred at $60{ }^{\circ} \mathrm{C}$ under $\mathrm{Ar}$ for $48 \mathrm{~h}$. After the starting material was consumed as monitored by TLC $\left(24 \mathrm{~h}\right.$ when $\mathrm{R}^{1}=\mathrm{Me}$ or $\mathrm{Cy}, 48 \mathrm{~h}$ when $\left.\mathrm{R}^{1}=t-\mathrm{Bu}\right)$, the reaction mixture was extracted with $\mathrm{Et}_{2} \mathrm{O}$. The combined extracts were dried over $\mathrm{MgSO}_{4}$, filtered, and concentrated under reduced pressure. The product was purified by column chromatography on silica gel (hexane/ ethyl acetate, yields, (S6): $\mathrm{R}^{1}=\mathrm{Cy}, \mathrm{R}^{2}=\mathrm{Me}, 4.7 \mathrm{~g}, 85 \% ; \mathrm{R}^{1}=t-\mathrm{Bu}, \mathrm{R}^{2}=$ Me, $3.6 \mathrm{~g}, 75 \%$; $\mathrm{R}^{1}=\mathrm{Bu}, \mathrm{R}^{2}=\mathrm{Bu}, 5.3 \mathrm{~g}, 90 \% ; \mathrm{R}^{1}=\mathrm{Bu}, \mathrm{R}^{2}=\mathrm{Ph}, 4.8 \mathrm{~g}$, $84 \%)^{26}$

(E)-Enyne esters S6 was converted to corresponding enyne aldehydes (S7) following a described method, ${ }^{12}$ and conversion of $\mathbf{S} 7$ to the corresponding enyne carbonates was performed as specified for $(E)$-1d. All synthesized substrates appeared colorless oils $((E)-1 \mathbf{e}$ : 0.44 g, 18\%; (E)-1f: 0.47 g 19\%; (E)-1h: 0.5 g 20\%; (E)-1i: 0.51 g, $20 \%)$

(E)-1e: ${ }^{1} \mathrm{H}$ NMR $\left(400 \mathrm{MHz}, \mathrm{CDCl}_{3}\right) \delta 5.97(\mathrm{~d}, J=8.8 \mathrm{~Hz}, 1 \mathrm{H})$, 5.48-5.41 (m, $1 \mathrm{H}), 3.75(\mathrm{~s}, 3 \mathrm{H}), 2.48-2.43(\mathrm{~m}, 1 \mathrm{H}), 1.88(\mathrm{~s}, 3 \mathrm{H})$, $1.84-1.77(\mathrm{~m}, 2 \mathrm{H}), 1.74-1.66(\mathrm{~m}, 2 \mathrm{H}), 1.51-1.39(\mathrm{~m}, 3 \mathrm{H}), 1.36-$ $1.25(\mathrm{~m}, 6 \mathrm{H}) ;{ }^{13} \mathrm{C}$ NMR $\left(101 \mathrm{MHz}, \mathrm{CDCl}_{3}\right) \delta 155.3,133.7,122.5$, 93.6, 82.5, 71.7, 54.7, 32.8, 29.7, 26.0, 25.0, 20.5, 18.4; FTIR $\left(\nu_{\max } /\right.$ $\left.\mathrm{cm}^{-1}\right): 3423,2931,2855,2217,1744,1443,1327,1257,1151,1036$, 939, 864, 791; MS (EI, $m / z) 250\left(4, \mathrm{M}^{+}\right), 191(45), 175(36), 159$ (29), 145 (24), 131 (54), 117 (42), 109 (100), 105 (74), 91 (93), 81 (44), 79 (47), 77 (40), 55 (34) 43 (55); HRMS (EI) calcd for $\mathrm{C}_{15} \mathrm{H}_{22} \mathrm{O}_{3} 250.1564$, found 250.1557 .

(E)-1f: ${ }^{1} \mathrm{H}$ NMR $\left(400 \mathrm{MHz}, \mathrm{CDCl}_{3}\right) \delta 5.66(\mathrm{dd}, J=9.2,1.2 \mathrm{~Hz}$, $1 \mathrm{H}), 5.44(\mathrm{dq}, J=9.2,6.4 \mathrm{~Hz}, 1 \mathrm{H}), 3.75(\mathrm{~s}, 3 \mathrm{H}), 1.87(\mathrm{~s}, 3 \mathrm{H}), 1.34(\mathrm{~d}$, $J=6.4 \mathrm{~Hz}, 3 \mathrm{H}), 1.22(\mathrm{~s}, 9 \mathrm{H}) ;{ }^{13} \mathrm{C} \operatorname{NMR}\left(101 \mathrm{MHz}, \mathrm{CDCl}_{3}\right) \delta 155.3$, 133.7, 122.5, 97.7, 81.0, 71.7, 54.7, 31.1, 27.9, 20.5, 18.4; FTIR $\left(\nu_{\max } /\right.$ $\left.\mathrm{cm}^{-1}\right) 2969,2929,2902,2868,2205,1744,1442,1327,1255,1150$, 1038, 948, 938, 864, 791; MS (EI, $m / z) 224\left(6, \mathrm{M}^{+}\right), 165$ (98), 167 (23), 149 (53), $133(74), 123(32), 121$ (41), 107 (54), 105 (100), 93 (44), 91 (96), 79 (41), 77 (42), 43 (90); HRMS (EI) calcd for $\mathrm{C}_{13} \mathrm{H}_{20} \mathrm{O}_{3}$ 224.1407, found 224.1403.

(E)-1h: ${ }^{1} \mathrm{H}$ NMR $\left(400 \mathrm{MHz}, \mathrm{CDCl}_{3}\right) \delta 5.66(\mathrm{~d}, J=9.4,1 \mathrm{H}), 5.46$ $(\mathrm{dq}, J=9.2,6.5 \mathrm{~Hz}, 1 \mathrm{H}), 3.74(\mathrm{~s}, 3 \mathrm{H}), 2.28(\mathrm{t}, J=6.8 \mathrm{~Hz}, 2 \mathrm{H}), 2.24-$ $2.10(\mathrm{~m}, 2 \mathrm{H}), 1.53-1.27(\mathrm{~m}, 11 \mathrm{H}), 0.9(\mathrm{t}, J=7.6 \mathrm{~Hz}, 6 \mathrm{H}) ;{ }^{13} \mathrm{C} \mathrm{NMR}$ $\left(101 \mathrm{MHz}, \mathrm{CDCl}_{3}\right) \delta 155.2,133.5,127.8,90.2,81.5,71.4,54.7,31.5$, 30.94, 30.75, 22.4, 22.1, 20.8, 19.1, 14.1, 13.7; FTIR $\left(\nu_{\max } / \mathrm{cm}^{-1}\right) 2957$, 2932, 2862, 2219, 1744, 1441, 1259, 1151, 1036, 941, 866, 791; MS (EI, $m / z) 266\left(1, \mathrm{M}^{+}\right), 207(24), 191$ (14), 161 (9), 148 (14), 119 (29), 105 (55), 91 (83), 77 (50), 55 (52), 43 (100); HRMS (ESI) calcd for $\mathrm{C}_{16} \mathrm{H}_{27} \mathrm{O}_{3}\left(\mathrm{MH}^{+}\right)$267.1956, found 267.1955. 
(E)-1i: ${ }^{1} \mathrm{H}$ NMR (400 MHz, $\mathrm{CDCl}_{3}$ ) $\delta 7.37-7.29(\mathrm{~m}, 5 \mathrm{H}), 5.99(\mathrm{~d}$, $J=5.6 \mathrm{~Hz}, 1 \mathrm{H}), 5.33(\mathrm{dq}, J=9.6,6.4 \mathrm{~Hz}, 1 \mathrm{H}), 3.73(\mathrm{~s}, 3 \mathrm{H}), 2.32(\mathrm{t}, J$ $=7.2 \mathrm{~Hz}, 2 \mathrm{H}), 1.55-1.40(\mathrm{~m}, 4 \mathrm{H}), 1.37(\mathrm{~d}, J=6.8 \mathrm{~Hz}, 3 \mathrm{H}), 0.91(\mathrm{t}, J$ $=7.4 \mathrm{~Hz}, 3 \mathrm{H}) ;{ }^{13} \mathrm{C}$ NMR $\left(101 \mathrm{MHz}, \mathrm{CDCl}_{3}\right) \delta: 154.9,137.4,135.1$, $128.48,128.43,128.1,127.3,91.7,81.5,72.3,54.7,30.8,22.1,20.8$, 19.2, 13.7; FTIR $\left(\nu_{\max } / \mathrm{cm}^{-1}\right) 3019,2957,2933,2873,1744,1442$, 1258, 1154, 1029, 941, 866, 791, 772, 736, 699; MS (EI, $m / z) 286$ (2, $\mathrm{M}^{+}$), 227 (25), 211 (20), 195 (18), 185 (14), 171 (23), 168 (51), 167 (39), 153 (35), 141 (24), 129 (22), 115 (21), 105 (8), 91 (22), 81 (21), 77 (13), 43 (100); HRMS (ESI) calcd for $\mathrm{C}_{18} \mathrm{H}_{23} \mathrm{O}_{3}\left(\mathrm{MH}^{+}\right)$ 287.1647, found 287.1642.

Method B. BuLi $(6.9 \mathrm{~mL}, 2.5 \mathrm{M}$ in hexane, $17.1 \mathrm{mmol})$ was added to a solution of tert-butylacetylene $(2 \mathrm{~mL}, 16.3 \mathrm{mmol})$ in dry THF $(40$ $\mathrm{mL}$ ) at $-78{ }^{\circ} \mathrm{C}$, and the solution was stirred for $45 \mathrm{~min}$ at this temperature. Methyl chloroformate $(1.4 \mathrm{~mL}, 1.71 \mathrm{mmol})$ was added subsequently, and the reaction mixture was allowed to warm slowly to $23{ }^{\circ} \mathrm{C}$ overnight. The reaction was quenched with $\mathrm{H}_{2} \mathrm{O}(20 \mathrm{~mL})$, and the mixture was extracted with $\mathrm{Et}_{2} \mathrm{O}(2 \times 50 \mathrm{~mL})$. The organic layers were then combined, washed with brine $(40 \mathrm{~mL})$, and dried over $\mathrm{MgSO}_{4}$. The solution of methyl 4,4-dimethylpent-2-ynoate (S5j) was concentrated in vacuo and was directly used in the next step. ${ }^{27}$

S5j $(2.8 \mathrm{~g}, 20 \mathrm{mmol})$ and 1-hexyne $(1.64 \mathrm{~g}, 20 \mathrm{mmol})$ were successively added to a mixture of $\mathrm{Pd}(\mathrm{OAc})_{2}(90 \mathrm{mg}, 2 \mathrm{~mol} \%)$ and tris(2,6-dimethoxyphenyl)phosphine (180 mg, $2 \mathrm{~mol} \%)$ in THF (30 $\mathrm{mL}$ ). The resulting mixture was stirred at room temperature until the reaction was judged complete by GC analysis. The mixture was concentrated and filtered through a short column with silica gel using hexane/EtOAc. The reaction produced the desired enyne ester S6j compound along with its regioisomer in 1:1 ratio (overall yield: $4.5 \mathrm{~g}$, $95 \%){ }^{28}$ The mixture of S6j and its regioisomer (Z)-ethyl 2-(2,2dimethylpropylidene)oct-3-ynoate was reduced to the corresponding primary enyne alcohols as specified previously. ${ }^{11,12}$ The enyne alcohol of desired isomeric form $\mathbf{S} \mathbf{j}$ could be separated from its regioisomer by silica gel column chromatrography (hexane/ethyl acetate, yield: 1.8 g, $48 \%)$. S2j was oxidized to yield the corresponding enyne aldehyde $\mathbf{S} 7 \mathbf{j}$ in $77 \%(1.4 \mathrm{~g})$, and $\mathbf{S} 7 \mathbf{j}$ was then subjected to Grignard reaction with $\mathrm{MeMgBr}$ following the procedures as described previously. ${ }^{11,12}$ The Grignard process partially isomerized the alkenyl moiety to produce 4-tert-butyldec-3-en-5-yn-2-ol (S3j) in 76\% yield $(1.18 \mathrm{~g})$ with an $E / Z$ ratio of $1.4: 1$. The carbonate functionalization of $S 3 \mathbf{j}$ was performed by following a specified method (hexane/ethyl acetate, colorless oil, yield: $1.3 \mathrm{~g}, 81 \%,(\mathrm{E}) /(\mathrm{Z})$ ratio: $1.4 / 1) .{ }^{25}$

1j: ${ }^{1} \mathrm{H}$ NMR $\left(400 \mathrm{MHz}, \mathrm{CDCl}_{3}\right) \delta 5.90-5.82(\mathrm{~m}, 1 \mathrm{H}, E), 5.69-$ $5.61(\mathrm{~m}, 3 \mathrm{H}), 3.76(\mathrm{~s}, 3 \mathrm{H}, \mathrm{Z}), 3.76(\mathrm{~s}, 3 \mathrm{H}, E), 2.38(\mathrm{t}, J=7.2 \mathrm{~Hz}, 2 \mathrm{H}$, Z), $2.30(\mathrm{t}, J=6.4 \mathrm{~Hz}, 2 \mathrm{H}, E), 1.59-1.39(\mathrm{~m}, 8 \mathrm{H}), 1.36(\mathrm{~d}, J=6.4 \mathrm{~Hz}$, $3 \mathrm{H}, Z), 1.35$ (d, $J=6.4 \mathrm{~Hz}, 3 \mathrm{H}, E), 1.25$ (s, 9H, E), 1.10 (s, 9H, Z), $0.93(\mathrm{t}, J=7.2 \mathrm{~Hz}, 3 \mathrm{H}, E), 0.91(\mathrm{t}, J=7.6 \mathrm{~Hz}, 3 \mathrm{H}, Z) ;{ }^{13} \mathrm{C}$ NMR $(100$ $\left.\mathrm{MHz} \mathrm{CDCl}_{3}\right) \delta(E): 155.1,133.9,129.8,89.7,82.1,71.8,54.6,35.7$, $30.9,29.0,21.99,21.1,18.9,13.59$; (Z) 155.0, 136.3, 134.8, 103.2, 98.1, 74.9, 54.5, 36.2, 30.8, 29.0, 21.98, 20.4, 19.2, 13.57. MS (EI, $m / z) 266$ $\left(2, \mathrm{M}^{+}\right), 207$ (8), 135 (4), 133 (14), 91 (20), 65 (40), 59 (62), 57 (52), 43 (69), 41 (100); HRMS (ESI) calcd for $\mathrm{C}_{16} \mathrm{H}_{27} \mathrm{O}_{3}\left(\mathrm{MH}^{+}\right)$ 267.1956, found 267.1986 .

Synthesis of Substrate (E)-1g. (Z)-Methyl 3-iodoacrylate, which was synthesized by hydroiodation of methyl propiolate using a reported procedure $(3.4 \mathrm{~g}, 84 \%){ }^{29}$ was isomerized to its $(E)$ configured form $((E) /(Z) ; 96: 4) .{ }^{30}$ Then, $(E)$-methyl 3-iodoacrylate was subjected to palladium-catalyzed coupling with 1-hexyne: The mixture of $(E)$-methyl 3-iodoacrylate $(\sim 25 \mathrm{mmol})$ in crude form, $\mathrm{PdCl}_{2}\left(\mathrm{PPh}_{3}\right)_{2}(151.2 \mathrm{mg}, 0.23 \mathrm{mmol})$, and $\mathrm{CuI}(23.5 \mathrm{mg}, 0.13 \mathrm{mmol})$ in $100 \mathrm{~mL}$ of $\mathrm{Et}_{3} \mathrm{~N}$ was stirred for $10 \mathrm{~min}$ at room temperature under Ar. 1-Hexyne $(28.8 \mathrm{mmol})$ was added to the resulting mixture and stirred at room temperature for $3 \mathrm{~h}$. At the end of the reaction, water was added to the mixture and extracted with $\mathrm{Et}_{2} \mathrm{O}$. The combined organic layers were dried over $\mathrm{MgSO}_{4}$. The solvent was evaporated in vacuo, and the enyne ester product $(\mathbf{S 6 g})$ was purified by column chromatography on silica gel (hexane/ethyl acetate, yield: $2.3 \mathrm{~g}, 88 \%$ ). $\mathbf{S 6 g}(10 \mathrm{mmol})$ was converted to $(E)-\mathbf{1 g}(0.59 \mathrm{mg}, 25 \%)$ as specified for $(E)-1$ e.
(E)-1g: colorless oil; ${ }^{1} \mathrm{H}$ NMR $\left(400 \mathrm{MHz}, \mathrm{CDCl}_{3}\right) \delta 5.98(\mathrm{dd}, J=$ $16.0,6.8 \mathrm{~Hz}, 1 \mathrm{H}$ ), $5.72(\mathrm{~d}, J=16 \mathrm{~Hz}, 1 \mathrm{H}), 5.19$ (quint, $J=6.8 \mathrm{~Hz}$, $1 \mathrm{H}), 3.76(\mathrm{~s}, 3 \mathrm{H}), 2.29(\mathrm{t}, J=6.8 \mathrm{~Hz}, 2 \mathrm{H}), 1.53-1.39(\mathrm{~m}, 4 \mathrm{H}), 1.36$ $(\mathrm{d}, J=6.4 \mathrm{~Hz}, 3 \mathrm{H}), 0.90(\mathrm{t}, J=7.2 \mathrm{~Hz}, 3 \mathrm{H}) ;{ }^{13} \mathrm{C}$ NMR $(101 \mathrm{MHz}$, $\mathrm{CDCl}_{3}$ ) $\delta 155.1,139.6,113.1,92.6,78.0,74.6,54.8,30.8,22.1,20.2$, 19.2, 13.7; FTIR $\left(\nu_{\max } / \mathrm{cm}^{-1}\right) 2958,2934,2873,2217,1745,1441$, 1256, 1154, 1036, 942, 868, 791; MS (EI, $m / z) 210\left(2, \mathrm{M}^{+}\right), 168(8)$, 151 (66), 135 (34), 119 (11), 109 (27), 105 (22), 95 (61), 91 (100), 79 (52), 77 (38), 65 (33), 43 (67); HRMS (EI) calcd for $\mathrm{C}_{12} \mathrm{H}_{18} \mathrm{O}_{3}$ 210.1251 , found 210.1250 .

Synthesis of Substrate (E)-10. A dry, two-necked, roundbottomed $250 \mathrm{~mL}$ flask equipped with a reflux condenser and an $\mathrm{Ar}$ gas inlet was filled with $75 \mathrm{~mL}$ of anhydrous absolute ethanol. Metallic sodium $(3.48 \mathrm{~g}, 150 \mathrm{mmol})$ was cut into small pieces and added into the ethanol and stirred. After all sodium was dissolved, diethyl malonate $(23 \mathrm{~mL}, 150 \mathrm{mmol})$ was added to the solution. The reaction mixture was treated with iodomethane $(9.8 \mathrm{~mL}, 157,5 \mathrm{mmol})$ by dropwise addition using a syringe and heated until the mixture reached its boiling point. After $4 \mathrm{~h}$, the reaction mixture was concentrated under reduced pressure and diluted with diethyl ether and water. Following phase separation, the aqueous layer was extracted with ether, and the combined extracts were dried over $\mathrm{MgSO}_{4}$, filtered, and evaporated in vacuo. The crude product diethyl 2-methylmalonate (S8) was used in the next step. ${ }^{31}$

The crude S8 $(\sim 50 \mathrm{mmol})$ was slowly added to the solution of $\mathrm{NaH}(25 \mathrm{~g}, 52 \mathrm{mmol})$ in $63 \mathrm{~mL}$ of dry $\mathrm{Et}_{2} \mathrm{O}$ via syringe, and the reaction mixture was refluxed again for $2.5 \mathrm{~h} . \mathrm{CHI}_{3}(19.8 \mathrm{~g}, 50 \mathrm{mmol})$ was added in one portion, and the mixture was refluxed for $20 \mathrm{~h}$. After the mixture was cooled to $0{ }^{\circ} \mathrm{C}$, hydrochloric acid solution $(18 \mathrm{~mL}$, $10 \%$ ) was added, and the resulting mixture was stirred for $\sim 10 \mathrm{~min}$. The organic phase was decanted, dried over $\mathrm{MgSO}_{4}$, filtered, and concentrated under a reduced pressure. The remaining residue was diluted with petroleum ether, and precipitated iodoform was removed by filtration. The product diethyl 2-(diiodomethyl)-2-methylmalonate (S9) was purified by distillation at $130{ }^{\circ} \mathrm{C}$ and $12 \mathrm{bar}$ (yield $=14.3 \mathrm{~g}$, $65 \%) .^{32}$

The solution of $59(\sim 33 \mathrm{mmol})$ and $\mathrm{KOH}(5.6 \mathrm{~g}, 0.1 \mathrm{~mol})$ in $\mathrm{EtOH} / \mathrm{H}_{2} \mathrm{O}(3: 1,45 \mathrm{~mL})$ was refluxed for $24 \mathrm{~h}$ and cooled to room temperature. The reaction mixture was concentrated under reduced pressure, diluted with an aqueous solution of $\mathrm{K}_{2} \mathrm{CO}_{3}(27 \mathrm{~mL}, \% 10)$, and washed with dichloromethane $(2 \times 9 \mathrm{~mL})$. The basic solution was acidified with $\mathrm{HCl}(\mathrm{aq})(12 \mathrm{M})$, and the aqueous phase was extracted with dichloromethane $(7 \times 7 \mathrm{~mL})$. The combined organic phases were dried over $\mathrm{MgSO}_{4}$, filtered, and concentrated under vacuum. (E)-3Iodo-2-methylacrylic acid (S10) was purified from the residue by crystallization with petroleum ether (yield $=12.9 \mathrm{~g} 89 \%$ ). ${ }^{32}$

Lithium aluminum hydride $(1.1 \mathrm{~g}, 29 \mathrm{mmol})$ was slowly added to the solution of $\mathbf{S 1 0}(\sim 29 \mathrm{mmol})$ in $48 \mathrm{~mL}$ of dry THF at $0{ }^{\circ} \mathrm{C}$ temperature under Ar. The reaction mixture was allowed to warm to room temperature and stirred for $3 \mathrm{~h}$. The reaction mixture was recooled to $0{ }^{\circ} \mathrm{C}$ and quenched with saturated aqueous $\mathrm{Na}_{2} \mathrm{SO}_{4}$ by dropwise addition. The mixture was diluted with ether, and $40 \mathrm{~mL}$ of aqueous $\mathrm{H}_{2} \mathrm{SO}_{4}(2 \mathrm{M})$ was added. The organic phase was decanted, and the aqueous phase was extracted with DCM. The combined organic phases were washed with $10 \mathrm{~mL}$ of aqueous $\mathrm{K}_{2} \mathrm{CO}_{3}(10 \%)$, and the aqueous phase was extracted with DCM. The combined organic phases were dried over $\mathrm{MgSO}_{4}$ and filtered, and the solvent was removed under vacuum. The product $(E)$-3-iodo-2-methylprop-2en-1-ol (S11) was purified by column chromatography on silica gel (hexane/ethyl acetate; yield $3.7 \mathrm{~g}, 65 \%$ ). $^{32}$

S11 was subjected to Sonogashira reaction with 1-hexyne. The Sonogashira product (E)-2-methylnon-2-en-4-yn-1-ol (yield: 86\%) was oxidized to (E)-2-methylnon-2-en-4-ynal and then subjected to Grignard reaction with $\mathrm{MeMgBr}$ following the procedures as described previously $^{11,12}$ to obtain (E)-3-methylhept-3-en-5-yn-2-ol (yield: $45 \%)$. Carbonate derivatization of this secondary was performed via a prescribed method (hexane $/ \mathrm{NEt}_{3}(1 \mathrm{vol} \%)$, colorless oil, yield $=1 \mathrm{~g}$, $62 \%){ }^{25}$

(E)-1o: ${ }^{1} \mathrm{H}$ NMR $\left(400 \mathrm{MHz}, \mathrm{CDCl}_{3}\right) \delta 5.55(\mathrm{~s}, 1 \mathrm{H}), 5.16(\mathrm{q}, J=$ $6.4 \mathrm{~Hz}, 1 \mathrm{H}), 3.76(\mathrm{~s}, 3 \mathrm{H}), 2.34(\mathrm{td}, J=6.8,1.6 \mathrm{~Hz}, 2 \mathrm{H}), 1.87(\mathrm{~s}, 3 \mathrm{H})$, 
$1.54-1.48(\mathrm{~m}, 2 \mathrm{H}), 1.47-1.40(\mathrm{~m}, 2 \mathrm{H}), 1.36(\mathrm{~d}, J=6.8 \mathrm{~Hz}, 3 \mathrm{H}), 0.92$ $(\mathrm{t}, J=6.8 \mathrm{~Hz}, 3 \mathrm{H}) ;{ }^{13} \mathrm{C}$ NMR $\left(101 \mathrm{MHz}, \mathrm{CDCl}_{3}\right) \delta 155.1,147.0$, 107.9, 95.8, 77.9, 77.3, 54.8, 31.1, 22.1, 19.4, 19.2, 14.9, 13.7; FTIR $\left(\nu_{\max } / \mathrm{cm}^{-1}\right) 2982,2957,2934,2861,2215,1746,1441,1328$, 1256,1067, 938, 871, 853, 791; MS (EI, $m / z) 224\left(4, \mathrm{M}^{+}\right), 165$ (31), 149 (15), 148 (12), 119 (13), 109 (25), 106 (37), 105 (50), 93 (26), 91 (100), 79 (32), 77 (31), 43 (40); HRMS (ESI) calcd for $\mathrm{C}_{13} \mathrm{H}_{20} \mathrm{O}_{3}\left(\mathrm{MH}^{+}\right)$225.1486, found 225.1485.

Preparation of Enantiopure Enyne Carbonates. ${ }^{14}$ For the preparation of corresponding enantiopure enynols of $(E)$ - and $(Z)-\mathbf{1 b}$ and $(E)-1 \mathbf{p} ; 1.0$ equiv of $\mathrm{Ti}(\mathrm{O}-\mathrm{i}-\mathrm{Pr})_{4}$ and 1.2 equiv of diisopropyl tartarate (DIPT) were stirred in dry DCM $(10 \mathrm{~mL} / \mathrm{mmol}$ of allylic alcohol) for $10 \mathrm{~min}$ between the temperatures of -25 and $-30{ }^{\circ} \mathrm{C}$ $\left(-20{ }^{\circ} \mathrm{C}\right.$ for the enynol of $\left.(Z)-1 \mathbf{b}\right)$. A dry DCM $(5 \mathrm{~mL})$ solution of 1.0 equiv of 2,4-enynol was added dropwise. After the mixture was stirred at the same temperature for $30 \mathrm{~min}, 2$ equiv of anhydrous TBHP (ca. 4-4.5 $\mathrm{M}$ in toluene) was added, and the homogeneous reaction mixture was maintained at $-20{ }^{\circ} \mathrm{C}$ (in a freezer) for $13 \mathrm{~h}$. After completion, $10 \%$ aqueous solution tartaric acid $(2.5 \mathrm{~mL} / \mathrm{mmol}$ of allylic alcohol) was added to the reaction mixture at $-20{ }^{\circ} \mathrm{C}$ while stirring, allowing the aqueous layer to solidify. After $30 \mathrm{~min}$, the cooling bath was removed, and stirring was continued at room temperature until the aqueous layer became clear. After separation of the aqueous layer, the organic layer was washed once with water, dried with $\mathrm{MgSO}_{4}$, and concentrated to yield colorless oil. This oil was diluted with ether, the resulting solution was cooled in an ice bath, and then $1 \mathrm{M}$ sodium hydroxide solution $(3 \mathrm{~mL} / \mathrm{mmol}$ of allylic alcohol) was added. The mixture was stirred for $30 \mathrm{~min}$, and the organic phase was recovered and washed with brine, dried with $\mathrm{MgSO}_{4}$, concentrated, and purified by column chromatography on silica gel (hexane/EtAc) to give a clear oil in $42 \%(0.35 \mathrm{~g}), 48 \%(0.37 \mathrm{~g})$, and $46 \%$ (0.38) yield, respectively. The enantiomeric purity of the enynols was determined by GC analysis using using a Hydodex $-\beta$-3P column $(25 \mathrm{~m}, 0.25 \mathrm{~mm} \mathrm{ID})$. Their hydroxyl groups were modified to carbonate as described above. For $(R, E)-1 \mathbf{b}$ : $98 \%$ ee, $[\alpha]^{18}{ }_{\mathrm{D}}=+37.0(c$ $\left.=7.75, \mathrm{CH}_{2} \mathrm{Cl}_{2}\right)$; for $(R, Z)-1 \mathbf{b}$ : $99 \%$ ee, $[\alpha]_{\mathrm{D}}^{22}=-14.6(c=3.92$, $\left.\mathrm{CH}_{2} \mathrm{Cl}_{2}\right)$; for $(R, E)-1 \mathrm{p}$ : $98 \%$ ee, $[\alpha]^{22}=+31.3\left(c=4.79, \mathrm{CH}_{2} \mathrm{Cl}_{2}\right)$.

For the preparation of the enynol of $(R, E)-\mathbf{1 f}, 0.3$ equiv of $\mathrm{Ti}(\mathrm{O}-i$ $\mathrm{Pr})_{4}$ and 0.36 equiv of DIPT were stirred in dry DCM $(10 \mathrm{~mL} / \mathrm{mmol}$ of allylic alcohol) at $-55{ }^{\circ} \mathrm{C}$. After the mixture was stirred for $10 \mathrm{~min}$, 1.0 equiv of enynol in 5-6 mL of dry DCM was added dropwise. After the mixture was stirred at the same temperature for $30 \mathrm{~min}, 2$ equiv of anhydrous TBHP (ca. 4-4.5 M in toluene) was added, and the homogeneous reaction mixture was stirred at the same temperature for 4 days and at $-35{ }^{\circ} \mathrm{C}$ for 1 day. After completion, the treatment and purification procedures were performed as described above (hexane/ EtAc, yield: $20 \%, 45 \mathrm{mg}$ ). Determination of its enantiomeric purity and carbonate derivatization were performed as described above. $(R, E)-1 f: 98 \%$ ee, $[\alpha]^{27}=+79.4\left(c=1.13, \mathrm{CH}_{2} \mathrm{Cl}_{2}\right)$.

General Procedure for Alkoxycarbonylation of Racemic Enyne Carbonates. The substrate, a palladium compound, ligand, and an alcohol $(5 \mathrm{~mL})$ were added successively to a Schlenk apparatus that was attached to an $\mathrm{Ar}$ line. A CO balloon was fixed to the reaction vessel, and the mixture was stirred magnetically in a preheated oil bath. The course of the reaction was followed by TLC and GC analyses. The solvent was evaporated at the end of the reaction, and the residue was purified by column chromatography on silica gel (hexane/EtOAc), affording the product. All of the vinylallene products appeared as colorless oils, and coupling constants of olefinic protons and NOE studies confirm $(E)$-configured structures. Except for 2pa, spectrometric data of vinylallene products can be found elsewhere (see Tables 1 and 2 for yield percentages; (E)-2ba, $54.9 \mathrm{mg}$; $(E)-\mathbf{2 b b}, 53.9 \mathrm{mg}$; (E)-2bc, $64.4 \mathrm{mg}$; (E)-2bd, $60.0 \mathrm{mg}$; (E)-2be, $47.4 \mathrm{mg}$; (E)-2ca, 32.9 mg; (E)-2da, $55.4 \mathrm{mg}$; (E)-2ea, $58.3 \mathrm{mg}$; $(E)-2 \mathrm{fa}, 41.8 \mathrm{mg}$; $(E)-2 \mathrm{ga}$, $51.8 \mathrm{mg}$; (E)-2ha, $67.5 \mathrm{mg}$; (E)-2ia, $62.4 \mathrm{mg}$; $(E)-2 \mathrm{ka}, 49.9 \mathrm{mg}$; $(E)$ 2la, $47.7 \mathrm{mg})^{11}$

2pa: yield 90\% (13.7 mg); $\left.{ }^{1} \mathrm{H} \mathrm{NMR} \mathrm{(400} \mathrm{MHz,} \mathrm{CDCl}_{3}\right) \delta 5.98(\mathrm{dt}$, $J=15.6,0.8 \mathrm{~Hz}, 1 \mathrm{H}), 5.77-5.69(\mathrm{~m}, 1 \mathrm{H}), 5.68-5.66(\mathrm{~m}, 1 \mathrm{H}), 3.72(\mathrm{~s}$, $3 \mathrm{H}), 1.89(\mathrm{~d}, J=2.8 \mathrm{~Hz}, 3 \mathrm{H}), 1.80(\mathrm{dd}, J=6.8,1.6 \mathrm{~Hz}, 3 \mathrm{H}), 1.26(\mathrm{~d}, J$ $=6.4 \mathrm{~Hz}, 3 \mathrm{H}) ;{ }^{13} \mathrm{C} \mathrm{NMR}\left(100 \mathrm{MHz}, \mathrm{CDCl}_{3}\right) \delta 215.7,166.3,127.4$,
125.6, 104.3, 87.3, 52.0, 18.4, 14.6; FTIR $\left(\nu_{\max } / \mathrm{cm}^{-1}\right)$ 2952, 1944, 1720, 1437, 1261, 1152, 1031, 961, 834; MS (EI, $m / z) 152\left(20, \mathrm{M}^{+}\right)$, 137 (20), 109 (40), 93 (48), 91 (95), 77 (99), 59 (100); HRMS (ESI) calcd for $\mathrm{C}_{9} \mathrm{H}_{13} \mathrm{O}_{2}\left(\mathrm{MH}^{+}\right)$153.0916, found 153.0911.

General Procedure for Alkoxycarbonylation of Enantiopure Enyne Carbonates. A palladium compound, phosphine ligand, and an alcohol $(0.5 \mathrm{~mL})$ were added successively to a Schlenk apparatus that is attached to an Ar line, and the mixture was stirred magnetically for about $1 \mathrm{~h}$. The reaction flask was adjusted to the reaction temperature, and $1.2 \mathrm{~mL}$ of a methanol solution of a substrate was added to the reaction flask. A balloon filled with $\mathrm{CO}$ was fixed to the reaction vessel, and the mixture was stirred magnetically at a prescribed temperature. Purification of the samples were performed as mentioned for those of racemic substrates. Enantiomeric exesses of $(S)$ - and $(R)$-2ba and $(S)$-2 fa vinylallene products were determined by HPLC methods. For $(S)$-2ba, HPLC conditions: OJ-H column, hexane $=0.4 \mathrm{~mL} / \mathrm{min}, \lambda=250 \mathrm{~nm}, t_{\mathrm{R}}$ (major) $=11.9 \mathrm{~min}, t_{\mathrm{R}}=$ (minor) $12.9 \mathrm{~min}$. For (R)-2ba, HPLC conditions: OJ-H column, hexane $/ i-\mathrm{PrOH}=200 / 1,0.4 \mathrm{~mL} / \mathrm{min}, \lambda=250 \mathrm{~nm}, t_{\mathrm{R}}$ (minor) $=10.5$ $\min , t_{\mathrm{R}}=$ (major) $11.2 \mathrm{~min}$. For $(S)$-2fa, HPLC conditions: Regis $(S, S)$ Whelk-O1 column, hexane $/ i-\mathrm{PrOH}=200 / 1,0.4 \mathrm{~mL} / \mathrm{min}, \lambda=250$ $\mathrm{nm}, t_{\mathrm{R}}($ major $)=26.1 \mathrm{~min}, t_{\mathrm{R}}=($ minor $) 28.2 \mathrm{~min}$. Enantiomeric purity of $(S)$-2pa was determined by a chiral GC method using a Hydodex- $\beta$ $3 \mathrm{P}$ column $(25 \mathrm{~m}, 0.25 \mathrm{~mm}$ i.d.).

\section{ASSOCIATED CONTENT}

\section{(S) Supporting Information}

${ }^{1} \mathrm{H}$ and ${ }^{13} \mathrm{C}$ spectra of $(E)-\mathbf{1 d}-\mathbf{i}, \mathbf{m}, \mathbf{o}, \mathbf{p},(E, Z)-\mathbf{1 j}$, and $\mathbf{2 p a}$ and chromatograms of enantioenriched compounds. This material is available free of charge via the Internet at http://pubs.acs.org.

\section{AUTHOR INFORMATION}

\section{Corresponding Author}

*E-mail: leventartok@iyte.edu.tr

\section{Notes}

The authors declare no competing financial interest.

\section{ACKNOWLEDGMENTS}

The financial support of the Scientific and Technological Research Council of Turkey and Federal Ministry of Education and Research (Germany) via the Intensified Cooperation Program (210T092) is gratefully acknowledged. We thank the Salih Research Group, SAREG, of the Chemistry Department of Hacettepe University and Mass Spectrometry Laboratory of Dortmund University of Technology for HRMS analyses.

\section{DEDICATION}

Dedicated to the memory of Dr. Ritchie C. Eanes.

\section{REFERENCES}

(1) (a) Krause, N.; Hashimi, A. S. K. Modern Allene Chemistry; WileyVCH: Weinheim, 2004. (b) Hoffman-Röder, A.; Krause, N. Tetrahedron 2004, 60, 11671. (c) Yu, S.; Ma, S. Chem. Commun. 2011, 47, 5384

(2) (a) Mikami, K.; Yoshida, A. Angew. Chem., Int. Ed. Engl. 1997, 36, 858. (b) Wang, Y.; Zhang, W.; Ma, S. J. Am. Chem. Soc. 2013, 135, 11517. (c) Krause, N.; Purpura, M. Angew. Chem., Int. Ed. 2000, 39, 435. (d) Cai, F.; Pu, X.; Qi, X.; Lynch, V.; Radha, A.; Ready, J. M. J. Am. Chem. Soc. 2011, 133, 18066. (e) Nishimura, T.; Makino, H.; Nagaosa, M.; Hayashi, T. J. Am. Chem. Soc. 2010, 132, 12865. (f) Ogasawara, M. Tetrahedron: Asymmetry 2009, 20, 259. (g) Miura, T.; Shimada, M.; Ku, S.-Y.; Tamai, T.; Murakami, M. Angew. Chem., Int. Ed. 2007, 46, 7101. (h) Crouch, I. T.; Neff, R. K.; Frantz, D. E. J. Am. Chem. Soc. 2013, 135, 4970.

(3) (a) Ma, S. Acc. Chem. Res. 2003, 36, 701. (b) Ma, S. Chem. Rev. 2005, 105, 2829. 
(4) (a) Marshall, J. A.; Wolf, M. A. J. Org. Chem. 1996, 61, 3238. (b) Hoffman-Röder, A.; Krause, N. Angew. Chem., Int. Ed. 2004, 43, 1196. (c) Ma, S.; Wu, S. Chem. Commun. 2001, 441. (d) Volz, F.; Krause, N. Org. Biomol. Chem. 2007, 5, 1519. (e) Sun, T.; Deutsch, C.; Krause, N. Org. Biomol. Chem. 2012, 10, 5965. (f) Volz, F.; Wadman, S. H.; Hoffmann-Röder, A.; Krause, N. Tetrahedron 2009, 65, 1902. (g) Miura, T.; Shimada, M.; de Mendoza, P.; Deutsch, C.; Krause, N.; Murakami, M. J. Org. Chem. 2009, 74, 6050.

(5) (a) Elsevier, C. J.; Kleijn, H.; Ruitenberg, K.; Vermeer, P. J. Chem. Soc., Chem. Commun. 1983, 1529. (b) Elsevier, C. J.; Kleijn, H.; Boersma, J.; Vermeer, P. Organometallics 1986, 5, 716. (c) Wouters, J. M. A.; Klein, R. A.; Elsevier, C. J. Organometallics 1994, 13, 4586. (d) Canty, A. J.; Jin, H.; Penny, J. D. J. Organomet. Chem. 1999, 573, 3035

(6) (a) Tsuji, J.; Mandai, T. Angew. Chem., Int. Ed. Engl. 1995, 34, 2589. (b) Ma, S. Eur. J. Org. Chem. 2004, 1175.

(7) Dixneuf, P. H.; Guyot, T.; Nessb, M. D.; Roberts, S. M. Chem. Commun. 1997, 2083.

(8) Marshall, J. A.; Wolf, M. A.; Wallace, E. M. J. Org. Chem. 1997, $62,367$.

(9) (a) Elsevier, C. J.; Stehouwer, P. M.; Westmijze, H.; Vermeer, P. J. Org. Chem. 1983, 48, 1103. (b) Molander, G. A.; Sommers, E. M.; Baker, S. R. J. Org. Chem. 2006, 71, 1563.

(10) (a) Piotti, M. E.; Alper, H. J. Org. Chem. 1997, 62, 8484.

(b) Yoshida, M.; Ueda, H.; Ihara, M. Tetrahedron Lett. 2005, 46, 6705.

(c) Yoshida, M.; Hayashi, M.; Shishido, K. Org. Lett. 2007, 9, 1643.

(11) Akpınar, G. E.; Kuş, M.; Üçüncü, M.; Karakuş, E.; Artok, L. Org. Lett. 2011, 13, 748.

(12) An extended version of the method involves the reaction of enyne carbonates and organoboronic acids, which yields aryl vinylallenes: Üçüncü, M.; Karakuş, E.; Kuş, M.; Akpınar, G. E.; Aksın-Artok, Ö.; Krause, N.; Karaca, S.; Elmac1, N.; Artok, L. J. Org. Chem. 2011, 76, 5959.

(13) This $\mathrm{S}_{\mathrm{N}} 2$-type product was also determined to form in the absence of the palladium catalyst.

(14) (a) Martin, V. S.; Woodard, S. S.; Katsuki, T.; Yamada, Y.; Ikeda, M.; Sharpless, K. B. J. Am. Chem. Soc. 1981, 103, 6237. (b) Kitano, Y.; Matsumoto, T.; Sato, F. J. Chem. Soc., Chem. Commun. 1986, 1323.

(15) The Lowe-Brewster rule was used to correlate the sign of optical rotation with the absolute configuration of the allene: (a) Lowe, G. Chem. Commun. 1965, 411. (b) Brewster, J. H. Top. Stereochem. 1967, 2, 33.

(16) (a) Trost, B. M.; Verhoeven, T. R. J. Am. Chem. Soc. 1978, 100, 3435. (b) Hayashi, T.; Hagihara, T.; Konishi, M.; Kumada, M. J. Am. Chem. Soc. 1983, 105, 7767. (c) Granberg, K. L.; Jan-E. Bäckvall, J.-E. J. Am. Chem. Soc. 1992, 114, 6858.

(17) All our attempts to convert a secondary 2-en-4-yne alcohol to its corresponding mesylate ${ }^{4 a, 8}$ and phosphate ${ }^{9}$ derivatives in order to implement a better leaving group to the structure failed due to decomposition.

(18) Such a trend was also observed for the alkoxycarbonylation reactions of conjugated enyne oxiranes: Kuş, M.; Artok, L. Manuscript in preparation.

(19) Reactions of enantiopure 2-en-4-yne acetates and organocuprates is the only example of the 1,5-substitution type reaction of conjugated enyne systems hitherto reported in the literature: Krause, N.; Hoffman-Röder, A. Angew. Chem., Int. Ed. 2000, 39, 4355.

(20) For the reaction of $(R, E)-1$ f, the catalyst was added in two portions: $6 \mathrm{~mol} \%$ of $\mathrm{Pd}$ and $12 \mathrm{~mol} \%$ of ligand in $1.7 \mathrm{~mL}$ of $\mathrm{MeOH}$ initially, and the remaining portion was added in $0.5 \mathrm{~mL}$ of $\mathrm{MeOH}$ after $48 \mathrm{~h}$ of reaction.

(21) (a) Trost, B. M.; Verhoeven, T. R. J. Org. Chem. 1976, 41, 3215. (b) Hayashi, T.; Yamamoto, A.; Hagihara, T. J. Org. Chem. 1986, 51, 723.

(22) Faller, J. W.; Thomsen, M. E.; Mattina, M. J. J. Am. Chem. Soc. 1971, 93, 2642.

(23) Similarly, a palladium-catalyzed carbonylative reaction of a phenyl-substituted secondary enynol in methanol was also shown to undergo allylic etherification: Gabriele, B.; Salerno, G.; De Pascali, F.;
Sciano, G. T.; Costa, M.; Chiusoli, G. P. Tetrahedron Lett. 1997, 38, 6877.

(24) Ukai, T.; Kawazura, H.; Ishii, Y.; Bonnet, J. J.; Ibers, J. A. J. Organomet. Chem. 1974, 65, 253.

(25) Chen, L.; Li, C. Tetrahedron Lett. 2004, 45, 2771.

(26) Zhao, S.; Ji, K.; Lu, L.; He, T.; Zhou, A.; Yan, R.; Ali, S.; Liu, X.; Liang, Y. J. Org. Chem. 2012, 77, 2763.

(27) Rooke, D. A.; Ferreira, E. M. Angew. Chem., Int. Ed. 2012, 51, 3225.

(28) Rubina, M.; Conley, M.; Gevorgyan, V. J. Am. Chem. Soc. 2006, $128,5818$.

(29) Piers, E.; Wong, T.; Coish, P. D.; Rogers, C. Can. J. Chem. 1994, $72,1816$.

(30) Garrais, S.; Turkington, J.; Goldring, W. P. D. Tetrahedron 2009, $65,8418$.

(31) Weiner, N. Org. Synth. 1937, 17, 56.

(32) Baker, R.; Castro, J. L. J. Chem. Soc., Perkin Trans. 1 1990, 47. 